Web: http://ejournal.unri.ac.id./index.php/JKFI Email: komunikasi.fisika.indonesia@gmail.com

\title{
MORFOLOGI DAN EFISIENSI SEL SURYA FOTOELEKTROKIMIA BERBASIS NANOSTRUKTUR ZnO DILAPISI TEMBAGA
}

\author{
Iwantono, Sella Natalia", Rinaldo Abdi, Awitdrus, Zulkarnain \\ ${ }_{1}^{1}$ Jurusan Fisika FMIPA UR, Kampus Bina Widya \\ Jl. HR. Soebrantas KM 12,5 Simpang Baru Panam, Pekanbaru 28293 \\ *E-mail korespondensi: sellanataliasimanungkalit@gmail.com
}

\begin{abstract}
$\mathrm{ZnO}$ nanostructures coated $\mathrm{Cu}$ (Copper) have been successfully grown using a method of seed mediated hydrotermal. The growth of $\mathrm{Cu}$ coated $\mathrm{ZnO}$ nanostructures were used as an active material of DSSC. The Cu on $\mathrm{ZnO}$ nanostructures has been coated at a concentration of $10 \mathrm{mM}$ at room temperature in 30 minutes. The samples were characterized using Field Emission Scanning Electron Microscope (FESEM), Energy Dispersive X-ray (EDX). The FESEM images showed that the geometrical shape of ZnO nanostructures was nanoflower. Spectra of EDX showed $\mathrm{Cu}$ was really exist in all samplesof about 0.8\%. A DSSC was fabricated by using the ZnO nanostructured coated $\mathrm{Cu}$ as an active material.The results of I-V measurements under iluminattion of halogen lamp its intensity of $100 \mathrm{~mW} / \mathrm{cm}^{2}$ has produced efficiency $0.35 \%$ (DSSC without copper) and increasedto 0,43\% whenCuwas coated on $\mathrm{ZnO}$.
\end{abstract}

Keywords: Nanostructure ZnO, Copper, Seed Mediated Hydrotermal, DSSC.

\begin{abstract}
ABSTRAK
Nanostruktur $\mathrm{ZnO}$ yang dilapisi $\mathrm{Cu}$ (Tembaga) telah berhasil ditumbuhkan menggunakan metode seed mediated hydrotermal. Penumbuhan nanostruktur $\mathrm{ZnO}$ yang dilapisi $\mathrm{Cu}$ digunakan sebagai material aktif pada DSSC. Pelapisan $\mathrm{Cu}$ pada nanostruktur ZnO dilakukan selama 30 menitpada suhu kamar dengan konsentrasi $10 \mathrm{mM}$. Sampel dikarakterisasi menggunakan Mikroskop Pindaian Emisi Medan Elektron (FESEM) dan Energi Dispersif Sinar-X (EDX) . Foto FESEM menunjukkan bahwa bentuk geometris dari nanostruktur ZnO dilapisi Cu adalah nanoflower. Spektrum EDX menunjukkan atom Cu benar-benar ada pada semua sampelsebesar0.8\%. Sel DSSC difabrikasi dengan menggunakan nanostruktur $\mathrm{ZnO}$ yang dilapisi Cu sebagai material aktifnya. Hasil pengukuran I$V$ dari DSSC pada intensitas penyinaran lampu halogen $100 \mathrm{~mW} / \mathrm{cm}^{2}$ menghasilkan efisiensi sebesar 0,35\% untuk sel tanpa lapisan $\mathrm{Cu}$ dan naik menjadi 0,43 \% ketika nanostruktur $\mathrm{ZnO}$ dilapisi $\mathrm{Cu}$.
\end{abstract}

Kata kunci: Nanostruktur ZnO, Tembaga, Seed Mediated Hydrotermal, DSSC.

\section{PENDAHULUAN}

Kebutuhan energi semakin lama semakin meningkat, sementara itu bahan bakar fosil semakin hari semakin berkurang. Alternatif baru pengganti bahan bakar fosil guna mengatasi masalah tersebut salah satunya adalah pemanfaatan cahaya matahari. Cahaya matahari merupakan salah satu sumber energi alternatif yang dapat diperbaharui dan memiliki banyak keunggulan, diantaranya ramah lingkungan, bersih, murah dan gratis. Untuk memanfaatkan cahaya matahari, diperlukan piranti yang dapat mengkonversikannya menjadi energi listrik, yaitu sel surya.

Michael Grätzel dan Brian O'Regan pada awal tahun 1990-an memperkenalkan sel surya lain yaitu Dye Sensitized Solar Cell (DSSC). DSSC merupakan sel surya generasi ketiga yang memanfaatkan teknologi foto elektrokimia dengan adanya elektrolit dan dye sensitizer serta menggunakan material aktif semikonduktor logam oksida $\left(\mathrm{TiO}_{2}, \mathrm{ZnO}\right)$.

Nanomaterial $\mathrm{ZnO}$ telah digunakan sebagai material aktif DSSC dengan menghasilkan nilai efisiensi sebesar 0,27\% [1], nilai ini masih jauh 
rendah dibandingkan sel Gratzel yang menggunakan $\mathrm{TiO} 2$ sebagai material aktifnya. Sehingga masih perlu dikembangkan dengan berbagai perlakuan dan modifikasi. Salah satu perlakuan yang telah dilakukan adalah dengan penambahan atom logam dan non-logam. ZnO dapat dilapisi dengan berbagai jenis logam seperti Ga, In, Sn, Mg, Al dan B [2]. Beberapa tahun terakhir ini $\mathrm{ZnO}$ banyak dimodifikasi dengan penambahan logam transisi (Ag) [3].

Logam transisi seperti $\mathrm{Cu}$ yang memiliki konduktivitas tinggi harganya murah dan tersedia di kerak bumi [4]. $\mathrm{ZnO}$ yang diberi tambahan $\mathrm{Cu}$ berpotensi dapat digunakan untuk meningkatkan sifat fisik, optik dan elektriknya, sehingga berpotensi dapat meningkatkan performansi DSSC.Untuk itu perlu dilakukan penelitian yang mengkaji penggunaan $\mathrm{Cu}$ pada $\mathrm{ZnO}$ dan efeknya pada efisiensi DSSC. Pada penelitian ini, dikaji pengaruh penambahan $\mathrm{Cu}$ pada nanomaterial $\mathrm{ZnO}$ dengan menggunakan metode seed mediated hydrotermal dan metode treatment.

\section{METODE PENELITIAN}

Metode penelitian yang digunakan pada penelitian ini adalah metode kimia basah, yaitu metode seed mediated hydrothermal untuk penumbuhan nanostruktur $\mathrm{ZnO}$. Pelapisan tembaga pada nanostruktur $\mathrm{ZnO}$ dengan konsentarsi $10 \mathrm{mM}$ menggunakan metode treatment (perendaman). Sintesis nanostruktur $\mathrm{ZnO}$ dilakukan melalui dua proses, yaitu proses pembenihan dan penumbuhan. Sedangkan karakterisasi sampel dilakukan dengan menggunakan metode FESEM dan EDX.

Bahan yang digunakan dalam penelitian ini yaitu: Hexamethylene Tetramine (HMT), Zinc Acetate Dihydrat (ZAD), Zinc Nitrat Hexahydrate (ZNH) dan Copper (II) Nitrat Hydrate. Larutan pembenih dibuat dengan melarutkan ZAD 0,01 M ke dalam $10 \mathrm{~mL}$ ethanol. Proses pembenihan selanjutnya dilakukan dengan menggunakan spin coater selama 30 detik dengan kecepatan $3.000 \mathrm{rpm}$. Setelah itu, sampel dianneling pada suhu $350^{\circ} \mathrm{C}$ selama 1 jam [5]. Proses penumbuhan diawali dengan membuat larutan penumbuh dengan mencampurkan ZNH 0,1 M dan HMT 0,1 M dalam $20 \mathrm{~mL}$ DI Water. Selanjutnya sampel yang telah dibenihkan kemudian dimasukkan ke dalam campuran larutan penumbuh. Setelah itu sampel dimasukkan ke dalam oven selama 8 jam pada suhu $90^{\circ} \mathrm{C}$ [5]. Selanjutnya proses pelapisan $\mathrm{Cu}$ dimulai dengan menyiapkan botol berisi $10 \mathrm{ml}$ DI water. Setelah itu sampel diletakkan dalam botol yang berisi larutan dengan posisi digantung selama 30 menit pada suhu kamar. Kemudian sampel dikeringkan dengan menggunakan oven selama 10 menit pada suhu $100^{\circ} \mathrm{C}$. Terakhir sampel dikarakterisasi dengan menggunakan FESEM dan EDX.

\section{HASIL DAN PEMBAHASAN}

Hasil pemindaian FESEM dari sampel yang dilapisi tembaga $(\mathrm{Cu})$ dan sampel murni dengan perbesaran 10.000X ditunjuk pada Gambar 1.
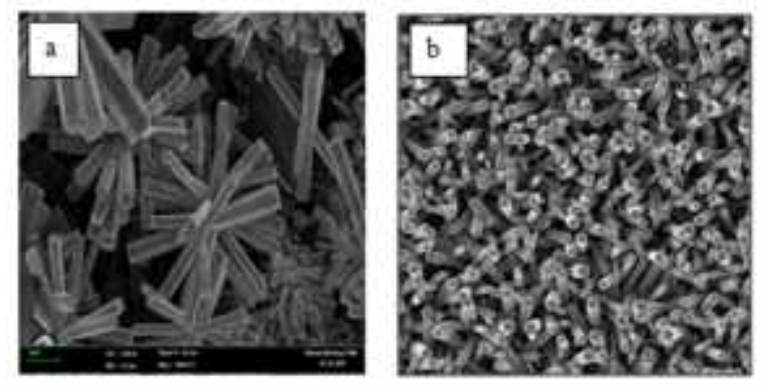

Gambar 1. Foto hasil pindaian FESEM nanostrukur $\mathrm{ZnO}$ yang dilapisi (a) $\mathrm{Cu} 10 \mathrm{mM}$ dan (b) $\mathrm{ZnO}$ murni dengan perbesaran 10.000X.

Gambar 1 menunjukkan bahwa nanostruktur $\mathrm{ZnO}$ yang tumbuh adalah nanostruktur $\mathrm{ZnO}$ berbentuk nanoflower, kontras dengan nanostruktur $\mathrm{ZnO}$ murni. Material $\mathrm{Cu}$ yang melapisi nanostruktur $\mathrm{ZnO}$ terlihat mempengaruhi struktur dari nanostruktur $\mathrm{ZnO}$. Nanostruktur $\mathrm{ZnO}$ yang dihasilkan pada sampel 
saling tumpang tidih yang artinya orientasinya tidak berdiri tegak atau vertikal terhadap FTO.

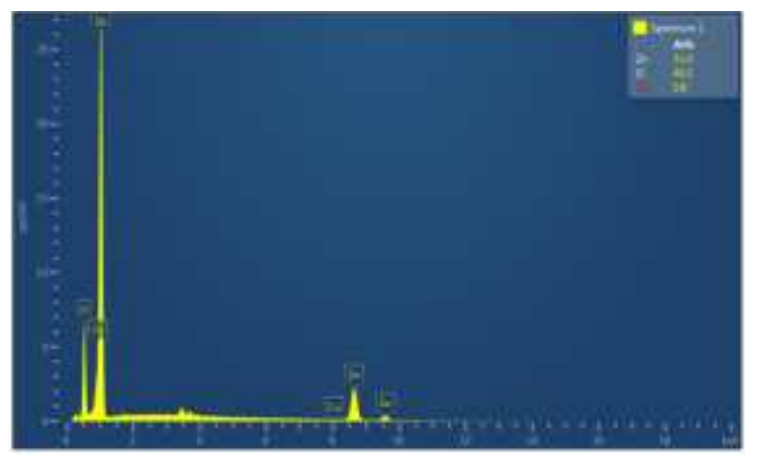

Gambar 2. Spektrum EDX dari nanostruktur $\mathrm{ZnO}$ yang dilapisi $\mathrm{Cu} 10 \mathrm{mM}$.

Gambar 2 memperlihatkan spektrum EDX dari nanostruktur $\mathrm{ZnO}$ yang dilapisi $\mathrm{Cu} 10 \mathrm{mM}$ yang terdiri dari Zn (Seng Oksida), O (Oksigen) dan $\mathrm{Cu}$ (Tenbaga). Hal ini membuktikan bahwa unsur $\mathrm{Cu}$ terdapat dalam sampel.

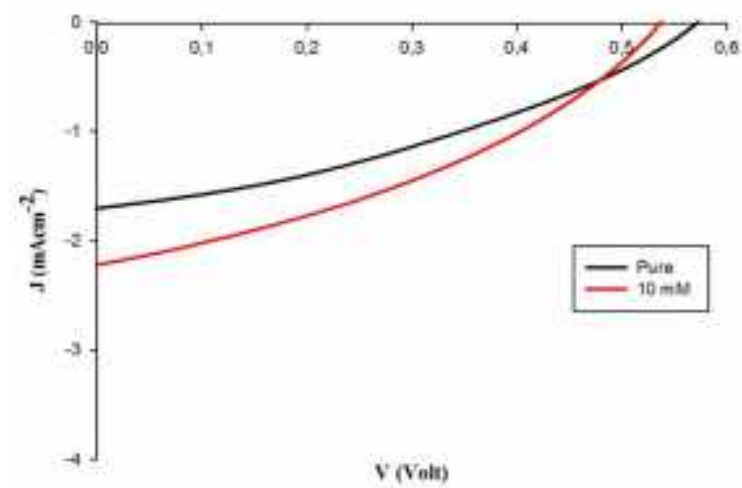

Gambar 3. Kurva J-V dalam keadaan terang (disinari) dari DSSC dengan material aktif nanostruktur $\mathrm{ZnO}$ murni dan nanostruktur $\mathrm{ZnO}$ yang dilapisi $\mathrm{Cu}$.

Karakteristik I-V dari Sel DSSC berbasis nanostruktur $\mathrm{ZnO}$ yang dilapisi $\mathrm{Cu}$ diperlihatkan pada Gambar 3. Gambar3 tersebut menunjukkan luasan daerah (daya maksimum) yang dihasilkan pada pengukuran I-V pada sel DSSC berbasis nanostruktur $\mathrm{ZnO}$ murni dan yang dilapisiCu. Tabel 1. menunjukkan parameter fisis sel hasil pengukuran dan perhitungannya pada kurva karakteristik I-V yang dihasilkan.
Tabel 1. Hasil data pengukuran dan perhitungan DSSC pada nanostruktur $\mathrm{ZnO}$ murni dan nanostruktur $\mathrm{ZnO}$ yang dilapisi $\mathrm{Cu}$.

\begin{tabular}{cccccc}
\hline No & Sampel & $\begin{array}{c}\mathrm{V}_{\mathrm{oc}} \\
(\mathrm{V})\end{array}$ & $\begin{array}{c}\mathrm{J}_{\mathrm{sc}} \\
\left(\mathrm{mAcm}^{-2}\right)\end{array}$ & FF & $\%$ \\
\hline 1 & $\begin{array}{c}\mathrm{ZnO} \\
\text { pure }\end{array}$ & 0,57 & 1,69 & 0,36 & 0,35 \\
& $10 \mathrm{mM}$ & 0,54 & 2,23 & 0,36 & 0,43 \\
\hline
\end{tabular}

Pada Tabel 1 tersebut dapat dilihat bahwa nilai efisiensi sel DSSC berbasis nanostruktur $\mathrm{ZnO}$ yang dilapisi $\mathrm{Cu}$ adalah $0,43 \%$ lebih besar dari efisiensi sel DSSC berbasis nanostruktur $\mathrm{ZnO}$ tanpa $\mathrm{Cu}$ sebesar 0,35\%.

Logam $\mathrm{Cu}$ memiliki konduktivitas tinggi yang dapat meningkatkan sifat fisis, optik dan elektriknya sehingga ketika $\mathrm{ZnO}$ dilapisi $\mathrm{Cu}$ dan kemudian diaplikan sebagai material aktif DSSC, maka dapat meningkatkan efisiensi DSSC.

\section{KESIMPULAN}

Nanostruktur $\mathrm{ZnO}$ dilapisi $\mathrm{Cu}$ telah berhasil ditumbuhkan di atas FTO sebagai material aktif DSSC menggunakan metode seed mediated hidrotermal engan konsentrasi larutan $\mathrm{Cu} 10$ $\mathrm{mM}$ selama 30 menit pada suhu kamar. Nanostruktur $\mathrm{ZnO}$ yang tumbuh adalah nanostruktur $\mathrm{ZnO}$ berbentuk nanoflower. Analisa kurva I-V dari DSSC menghasilkan nilai efisiensi sel setelah di lapisi $\mathrm{Cu}$ meningkat dari 0,35\% (sel berbasi snano struktur $\mathrm{ZnO}$ murni) menjadi $0,43 \%$.

\section{UCAPAN TERIMA KASIH}

Ucapan terima kasih disampaikan kepada Kemenristekdikti melalui DRPM yang telah mendanai peneltiian ini melalui Hibah Penelitian Kompetensi Tahun 2018 atas nama Dr. Iwantono, M.Phil dengan kontrak nomor: 362/UN.19.5.1.3/PP/2018 


\section{DAFTAR PUSTAKA}

1. Iwantono, Nurwidya, W., Lestari, L. R., Naumar, F. Y., Nafishah, Umar, A. A., Rahman, M. Y. A., \& Salleh, M. M. (2015). Effect of growth temperature and time on the $\mathrm{ZnO}$ film properties and the performance of dye sensitized solar cell (DSSC). Journal Solid State Electrochem.

2. Yun, S., Lee, J., Yang, J. \& Lim, S. (2010). Hydrothermal synthesis of al-doped ZnOnanorod arrays on si substrate. Physica B, Condensed matter, 405(1), 413-419.

3. Tan, T., Alzayed, N. S., Lakshminarayana, G., Naumar, F., Umar, A. A., Oyama, M., Myronchuk, G., \& Kityk, I. V. (2014). Laser stimulated electrooptics in the $\mathrm{Ag}-\mathrm{ZnO}$ nanorods. Physica E, 61, 23.
4. Labhane, K. P., Huse, R. V., Patle, B. L., Chaudhari, L. A., \& Sonawane, H. G. (2015). Synthesis of $\mathrm{Cu}$ Doped $\mathrm{ZnO}$ Nanoparticles: Crystallographic, Optical, FTIR, Morphological and Photocatalytic Study. Journal of Material Science and Chemical Engineering, 3, 39-51.

5. Anggelina, F. (2014). Efek Suhu dan Waktu Penumbuhan Nanorod $\mathrm{ZnO}$ dengan Metode Hidrotermal Untuk Aplikasi DSSC (Dye Sensitized Solar Cells), Skripsi Program Studi Fisika Fakultas Matematika dan Ilmu Pengetahuan Alam, Universitas Riau, Pekanbaru. 